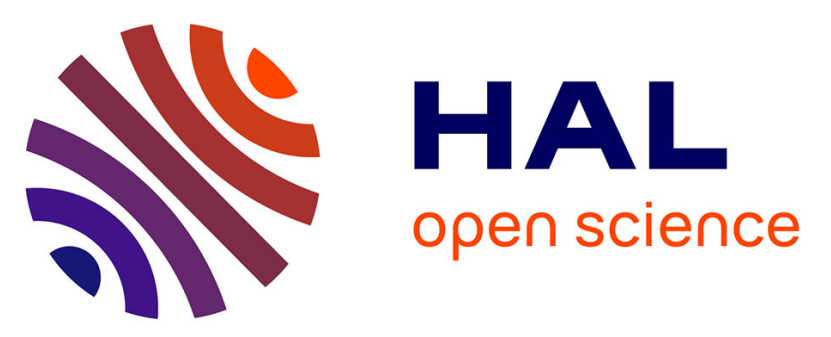

\title{
Quantitative immunohistochemical fingerprinting of adhesion/growth-regulatory galectins in salivary gland tumors: Divergent profiles with diagnostic potential
}

\author{
Myriam Remmelink, Laurence de Leval, Christine Decaestecker, Anaelle
} Duray, Nicolas Sirtaine, Emerence Crompot, Sabine André, Herbert Kaltner, Xavier Leroy, Hans-Joachim Gabius, et al.

\section{To cite this version:}

Myriam Remmelink, Laurence de Leval, Christine Decaestecker, Anaelle Duray, Nicolas Sirtaine, et al.. Quantitative immunohistochemical fingerprinting of adhesion/growth-regulatory galectins in salivary gland tumors: Divergent profiles with diagnostic potential. Histopathology, 2011, 58 (4), pp.543. 10.1111/j.1365-2559.2011.03776.x . hal-00624432

\section{HAL Id: hal-00624432 \\ https://hal.science/hal-00624432}

Submitted on 17 Sep 2011

HAL is a multi-disciplinary open access archive for the deposit and dissemination of scientific research documents, whether they are published or not. The documents may come from teaching and research institutions in France or abroad, or from public or private research centers.
L'archive ouverte pluridisciplinaire HAL, est destinée au dépôt et à la diffusion de documents scientifiques de niveau recherche, publiés ou non, émanant des établissements d'enseignement et de recherche français ou étrangers, des laboratoires publics ou privés. 


\section{Histopathology}

Quantitative immunohistochemical fingerprinting of adhesion/growth-regulatory galectins in salivary gland tumors: Divergent profiles with diagnostic potential

\begin{tabular}{|r|l|}
\hline Journal: & Histopathology \\
\hline Manuscript ID: & HISTOP-12-09-0696.R1 \\
\hline Danuscript Type: & Original Article \\
\hline Author: & 21-Apr-2010 \\
\hline Komplete List of Authors: & $\begin{array}{l}\text { remmelink, myriam } \\
\text { de Leval, Laurence; CHU Sart-Tilman, Pathology } \\
\text { decaestecker, christine; ULB, toxicology } \\
\text { duray, anaelle; University of Mons, laboratory of anatomy and } \\
\text { cellular biology } \\
\text { sirtaine, nicolas } \\
\text { crompot, emerence } \\
\text { andré, sabine } \\
\text { kaltner, herbert } \\
\text { leroy, xavier } \\
\text { Gabius, Hans-Joachim } \\
\text { Saussez, Sven; University of Mons-Hainaut, Laboratory of Anatomy }\end{array}$ \\
\hline Salivary gland, galectin, diagnosis, immunohistochemistry \\
\hline
\end{tabular}

\section{S) ScholaroNE \\ Manuscript Central}


First of all, as recommended by the associate editor and the reviewer 1 we have reduced the length of the manuscript of about $10 \%$.

\section{Answers to the reviewer 1:}

-In the Table 2, we provide a footnote explaining more precisely the data:

"For each type of tissue, the number of cases and the percentage of immunopositive cases relative to the intracellular localization are provided." We have also clarified the Table 2.

-As recommended, we rewritten the discussion more concisely and add a more elaborate part on the differential diagnostic implications for pathologists:

"The stratification based on intracellular distribution disclosed notable shifts and differences. For pathologists, this point could be relevant in the histopathological MEC diagnosis because these tumours presented a unique profile based on cytoplasmic localization of Gals-1, $-\mathbf{3},-\mathbf{- 7}$, and $\mathbf{- 8}$ in the intermediate cells. Here, combination with Gal-7 presence has potential to increase the reliability of subtype diagnosis to separate solid-pattern from tubular/cribriform-patterns malignancies. Moreover, the absence of Gal-7 expression is also observed in ACC. This could help with distinction from MEC, especially the microcystic variant of ACC. When material is limited, the differential diagnosis between ADCCs and PAs is sometimes challenging. Our study shows that the expression profile of Gals-1, -3 , and -7 is different when considering these histopathological specimens. In PA, the absence of nuclear Gal-1 signal and the cytoplasmic and nuclear presence of Gal-3 constitute a characteristic Gal-1, -3 signature, whereas the Gal-3 signal was confined to the cytoplasmic compartment of ADCCs."

-As recommended, key messages for pathologists are also add in the abstract: 
"Acinic cell and adenoid cystic carcinomas (specifically tubular and cribriform types) shared the expression signature of galectin-1, -3 and -8 presence combined with galectin7 absence. Mucoepidermoid carcinomas presented a unique profile based on cytoplasmic galectin 1-3-7-8 localization in the intermediate cells."

-As recommended, we add in the discussion a comment about the utility of galectin immunohistochemistry in routine laboratory:

"-page 13, line 2: "In summary, our study supports the concept for characteristic signatures of galectin presence when monitoring several proteins of this class, constituting progress in mapping presence of these lectins and indicating potential for differential diagnosis, especially for MEC/ACC."

\section{$\underline{\text { Answers to associate editor: }}$}

-As recommended by the associate editor and the reviewer 1 , we have reduced the length of the manuscript of about $10 \%$ (reduction of more than 300 words).

-In the abstract, we provide a clearly worded sentence on the aims/objectives of our study:

“Aims: Histopathological fingerprinting of galectins, emerging multifunctional effectors in cell sociology, is suggested to refine differential diagnosis. This hypothesis is tested for salivary tumours."

-As recommended, we provide in the table 1 a list of the histopathological type of tumour.

-In Table 2, 0 is written 0 and not $0 \%$. 
Remmelink et al.

\section{Quantitative immunohistochemical fingerprinting of adhesion/growth-regulatory}

\section{galectins in salivary gland tumours: Divergent profiles with diagnostic potential}

Myriam Remmelink, M.D, Ph.D. ${ }^{1}$, Laurence de Leval, M.D., Ph.D. ${ }^{2}$, Christine Decaestecker, Ph.D. ${ }^{3, *}$, Anaelle Duray ${ }^{4}$, Emerence Crompot ${ }^{4}$, Nicolas Sirtaine, M.D. ${ }^{5}$, Sabine André, Ph.D. ${ }^{6}$, Herbert Kaltner, Vet M.D. ${ }^{6}$, Xavier Leroy, M.D., Ph.D. ${ }^{7}$, Hans-Joachim Gabius, Ph.D. ${ }^{6}$, Sven Saussez, M.D., Ph.D. ${ }^{4}$

${ }^{1}$ Department of Pathology, Université Libre de Bruxelles (ULB), Brussels, Belgium.

${ }^{2}$ Department of Pathology, University of Liège, Liège, Belgium.

${ }^{3}$ Laboratory of Toxicology, Institute of Pharmacy, ULB, Brussels, Belgium.

${ }^{4}$ Laboratory of Anatomy and Cellular Biology, Faculty of Medicine and Pharmacy, University of Mons, Mons, Belgium.

${ }^{5}$ Department of Pathology, Institut Bordet, ULB, Brussels, Belgium.

${ }^{6}$ Institute of Physiological Chemistry, Faculty of Veterinary Medicine, Ludwig-Maximilians-University Munich, Munich, Germany.

${ }^{7}$ Department of Pathology, Faculty of Medicine,

Hôpital Claude Huriez and Centre de Biologie-Pathologie - CHRU, Lille, France.

*LL and CD are Senior Research Associate with the Belgian National Fund for Scientific Research (FNRS, Brussels, Belgium)

Running Title: Galectins in salivary gland cancer

\section{Corresponding author:}

S. Saussez, M.D., Ph.D.

Laboratory of Anatomy, Faculty of Medicine and Pharmacy

University of Mons

Pentagone 1B - Avenue du Champ de Mars, 6

B-7000 Mons, Belgium

Tel: 32-65-37 35 56; Fax: 32-65-37 3557

E-mail: sven.saussez@umons.ac.be 
Remmelink et al.

\begin{abstract}
Aims: Histopathological fingerprinting of galectins, emerging multifunctional effectors in cell sociology, is suggested to refine differential diagnosis. This hypothesis is tested for salivary tumours. Methods and results: We apply non-cross-reactive polyclonal antibodies against galectins-1, $-3,-7$, and -8 to immunohistochemical analysis of salivary gland tumours (72 cases with benign disease and 39 cases with malignancy, adding 29 specimens as control). The principal positivity of cases, the site of signal presence and the quantitative parameters concerning percentage of positive cells and labelling intensity were determined. Acinic cell and adenoid cystic carcinomas (specifically tubular and cribriform types) shared the expression signature of galectin-1, -3 and 8 presence combined with galectin-7 absence. Mucoepidermoid carcinomas presented a unique profile based on cytoplasmic galectin 1-3-7-8 localization in the intermediate cells. Adenomas were separable from malignancy by a consistent decrease of the Labeling Index for galectins-7 and 8 (LI Gal-7, $\mathrm{p}<10^{-6} ;$ LI Gal-8, $\left.\mathrm{p}=0.001\right)$. When present, staining for the tumour suppressor $\mathrm{p} 16^{\mathrm{INK} 4 \mathrm{a}}$ coincided with galectin-1 presence. Conclusions: Thus, expression profiling of the tested four galectins in salivary gland tumours revealed non-uniform staining patterns with discriminatory potency based on intracellular localization and quantitative aspects.
\end{abstract}

Key Words: diagnosis, galectin, immunohistochemistry, salivary gland 
Remmelink et al.

\section{Introduction}

Proteins serving as multifunctional effectors are promising candidates as markers in histopathology. When gene diversification has led to a family of homologous proteins it is an attractive project line to define individual expression profiles comparatively in tumour material. Respective studies may reveal new diagnostic tools and insights into clinical correlations. Toward this end we focus on a family of endogenous lectins regulating cell adhesion and growth, i.e. the galectins sharing the $\beta$-sandwich fold $(1,2)$. Systematic RT-PCR screening on tumour cell lines has revealed that galectin expression is subject to intricate control $(3,4)$. Using non-crossreactive antibodies presence of distinct members of the three subgroups, i.e. proto-type, chimera-type and tandem-repeat-type proteins, in routine tissue sections can be detected $(5,6)$. Thus, questions on relation of galectins to malignancy and on contributions to differential diagnosis can hereby be answered.

Previous work on salivary gland tumors has attracted our attention in this respect. Presence of galectins-1 and -3 (Gal-1 and Gal-3) was initially described, further work extending the data basis for Gal-3 with its potential to distinguish polymorphous low-grade adenocarcinoma from adenoid cystic carcinoma (AdCC) remaining controversial (7-11). Since the tandem-repeat-type protein Gal-8, is of prognostic relevance in bladder and colon (Dukes C/D) cancer $(12,13)$, it was also monitored. Prototype Gal-7 completes our panel of four galectins due to its proven regulation by the tumour suppressor p53, its effectiveness as growth regulator, and its characteristic distribution different from Gal-1 in laryngeal/hypopharyngeal squamous cell carcinomas $(5,14-18)$. Since Gal-1 expression is under the control of $\mathrm{p} 16^{\mathrm{INK} 4 \mathrm{a}}$ in vitro (19), detection of this tumour suppressor protein together with p53 was performed in serial sections. In total, we studied material from 111 cases of salivary gland tumours (SGTs), assessing positivity first, then localization and finally quantitative parameter on percentage of stained area and signal intensity. The questions on i) distribution profiles of the four 
Remmelink et al.

galectins and their individual characteristics in benign and malignant lesions, ii) differences between tumour types and iii) any relation to the tumour suppressors will be answered. 
Remmelink et al.

\section{Materials and Methods}

\section{Patients' Characteristics}

A total of 111 tumour cases, comprised of 72 patients with benign SGTs and 39 patients with malignant SGTs who underwent surgery aimed at curative tumour resection, were studied (see Table 1 for clinical data). In 29 specimens of Warthin's tumour, intra- and interlobular ducts in adjacent tumour-free parotid tissue was evaluated. Tumour specimens were obtained by retrospective compilation from the records of the Departments of Pathology of the Hôpital Claude Huriez (XL, Lille, France), the Hôpital Erasme (MR, Brussels, Belgium), the CHU Saint-Pierre-Institut Bordet (NS, Brussels, Belgium) and the CHU Sart-Tilmant (LD, Liège, Belgium). The Institutional Review Boards of these hospitals approved the study.

H\&E sections of the 111 tumours were examined by two pathologists to confirm the diagnosis and then processed immunohistochemically under identical conditions to semiquantitatively and quantitatively monitor presence of Gals- $1,-3,-7$ and -8 and the two tested tumour suppressor proteins.

\section{Antibodies}

To raise polyclonal antibodies in rabbits, human Gals-1, $-3,-7$ and -8 were produced in bacteria, purified to homogeneity as ascertained by one- and two-dimensional gel electrophoresis and mass spectrometry and then used as antigens $<<<$ PLEASE INSERT HERE REF 13, 16, 19>>>>. The immunoglobulin $G$ fractions resulting from protein A-Sepharose affinity chromatography were rigorously checked for cross-reactivity among this lectin family systematically testing human Gals-1, $2,-3,-4,-7,-8$ and -9 in Western blot and ELISA assays, and chromatographic affinity depletion was performed in any case of positivity followed by quality controls to verify complete elimination of cross-reactivity as described previously (20).

\section{Immunohistochemistry}

All tumour samples were fixed for $24 \mathrm{~h}$ in $10 \%$ buffered formaldehyde, dehydrated and routinely embedded in paraffin. Immunohistochemistry was routinely performed on $5 \mu \mathrm{m}$-thick sections 
Remmelink et al.

mounted on silane-coated glass slides, as detailed recently $(5,21)$. Before starting the immunohistochemistry protocol, dewaxed tissue sections were briefly subjected to microwave pretreatment in a $0.01 \mathrm{M}$ citrate buffer $(\mathrm{pH} 6.0)$ for $2 \times 5$ min at $900 \mathrm{~W}$. The sections were then incubated with a solution of $0.4 \%$ hydrogen peroxide for five min to block endogenous peroxidase activity, rinsed in phosphate-buffered saline (PBS; $0.04 \mathrm{M} \mathrm{Na}_{2} \mathrm{HPO}_{4}, 0.01 \mathrm{M} \mathrm{KH}_{2} \mathrm{PO}_{4}$ and $0.12 \mathrm{M}$ $\mathrm{NaCl}, \mathrm{pH} 7.4)$ and successively exposed for $20 \mathrm{~min}$ to solutions containing avidin $(0.1 \mathrm{mg} / \mathrm{ml}$ in PBS $)$ and biotin $(0.1 \mathrm{mg} / \mathrm{ml}$ in PBS) to avoid false-positive staining reactions resulting from endogenous biotin. After a thorough washing with PBS to remove the reagents, the sections were incubated for 20 min with a solution of $0.5 \%$ casein in PBS, again carefully washed and thereafter sequentially exposed at room temperature to solutions of i) the specific primary anti-galectin antibodies; ii) the corresponding biotinylated secondary antibody (polyclonal goat anti-rabbit IgG); and iii) the avidinbiotin-peroxidase complex (ABC kit). Incubation steps were separated by thorough washing steps to remove any unbound proteins. Antigen-dependent presence of the peroxidase complex in the sections was visualized by incubation with solution containing the chromogenic substrates diaminobenzidine and $\mathrm{H}_{2} \mathrm{O}_{2}$. After rinsing, the sections were counterstained with luxol fast blue and mounted with a synthetic medium. To exclude antigen-independent staining, the incubation step with primary/secondary antibodies was omitted from the protocol in controls. In all cases these controls were negative. The biotinylated secondary antibodies and the $\mathrm{ABC}$ kit came from DakoCytomation

(Glostrup, Denmark), antibodies against the tumour suppressors p16 ${ }^{\mathrm{INK} 4 \mathrm{a}}$ from Abcam (Cambridge, UK) and p53 from DakoCytomation.

\section{Semi-quantitative analysis}

For each specimen (15 microscopic fields), the intensity of the immunostaining (Mean Intensity, MI) was scored as 0 (negative), 1 (weak), 2 (moderate) or 3 (strong), and its presence (Labelling Index, LI) was graded into categories of percentage of positive cells as $0(0 \%$ positive cells), $1(1-25 \%), 2(>25 \%$ 
Remmelink et al.

and $<75 \%)$ or $3(>75 \%$ up to $100 \%)$. The quick score (QS) was calculated by multiplying the score of intensity of reactivity with the category of the percentage of immunopositive cells.

\section{Quantitative analysis using computer-assisted microscopy}

Following the immunohistochemical processing steps, the quantitative aspects of signal intensity and distribution were determined using a computer-assisted KS 400 imaging system (Carl Zeiss Vision, Hallbergmoos, Germany) connected to a Zeiss Axioplan microscope, as detailed previously (17). For each microscopic field, we focused analysis on the tumoural region using computer-assisted morphometry after interactive identification. In each case, we scanned 15 fields covering a surface area ranging from 60,000 to $120,000 \mu \mathrm{m}^{2}$. In each case, the quantitative analysis of immunohistochemical staining for a given marker yielded data on two variables: 1) the Labelling Index (LI), i.e. the percentage of positive cells, and 2) the Mean Optical Density (MOD), i.e. staining intensity of positive cells (17). For each case of SGTs, the respective fields were defined by one of us (MR, XL, LD, NS) specialised in this diagnostic procedure.

\section{Data analysis}

Independent groups of quantitative data were compared using the non-parametric Kruskall-Wallis (more than two groups). In the case of more than two groups, post-hoc tests (Dunn procedure) were used to compare pairs of groups (to avoid multiple comparison effects). The statistical analyses were carried out using Statistica software (Statsoft, Tulsa, USA). 
Remmelink et al.

\section{Results}

Our study started with comparative analysis of the staining profiles of the four antibody preparations in 29 control cases, examining the adjacent tumour-free tissue in sections of Warthin's tumour. Whereas acini were generally negative, a clear difference was seen between Gal-1, here lymphoid cells serving as positive controls (Fig. 1A, B), and the other three types of galectins (Fig.1A-F). The profiles of Gal-7 immunopositivity in intra- and interlobular ducts were remarkably comparable. Both types of duct (intra- and interlobular) presented very strong cytoplasmic and nuclear immunostaining of the basal layer and moderate cytoplasmic expression in the luminal layer (Fig. 1E, F). Of particular note, nucleocytoplasmic presence was detected in inter- and intralobular ducts consistently for Gals-1, -3 and -7 (Fig. 1A-F). In contrast, Gal-8 was exclusively cytoplasmic (Fig. 1G, H; Table 2).

Moving on to benign lesions, these cases were first classified. 44 out of the 72 cases $(66 \%)$ of pleomorphic adenoma (PA) presented both epithelial and chondroid compartments. These two components are shown separately in Fig. 2A-H, revealing moderate to strong nucleocytoplasmic positivity for Gal-1 in $73 \%$ or $75 \%$ of the cases, respectively (Fig. 2A, E; Table 2). Gal-3 presence was detected in $68 \%$ of the cases with epithelial component, showing either cytoplasmic (59\%) or also nucleocytoplasmic positivity (44\%) (Fig. 2B; Table 2). Also, the chondroid component was positive for Gal-3 in $50 \%$ of the cases with similar intracellular distribution (Fig. 2F). While the epithelial part harboured Gal-7 in $60 \%$ of the cases with nucleocytoplasmic localization, only $33 \%$ presented a signal for the chondroid part (Fig. 2C, G; Table 2). In contrast, Gal-8 expression was abundant in $90 \%$ and $82 \%$ in these two components, with staining seen both in the cytoplasm and in nuclei (Fig. 2D,H; Table 2). PA formation is apparently associated with a shift of Gal-3 from nuclear also to cytoplasmic sites and of Gal-8 from exclusively cytoplasmic also to nuclear sites, maintaining the 
Remmelink et al.

cytoplasmic presence (Table 2). Regarding frequency, there appears to be a graded occurrence instead of uniform expression with a ranking from Gal-8, then to Gal-1, -3 and -7 in terms of positivity by cases.

Analysis of the adenoid cystic carcinomas (AdCC; total of 15 cases) was subdivided into cases with solid (eight patients), cribriform (five patients) and tubular patterns (two patients). Gal-1 was invariably present in tumour cells, detected both in nuclei and in cytoplasm (66\%) or exclusively in nuclei (markedly for cribriform types, not at all for solidpattern-type tumours) and in stroma (Fig. 3A-C; Table 2). All eight cases with the solid pattern showed nucleocytoplasmic presence (Table 2). In contrast to Gal-1, peritumoral cells were consistently negative for Gal-3, while 13 from 15 cases yielded cytoplasmic signals of weak to moderate intensity (Fig. 3D-F; Table 2). No nuclear signals were seen. In terms of subtype selectivity no immunopositivity for Gal-7 was detected in tubular tumors, only one cribriform tumour was positive, solid ones revealing strong nucleocytoplasmic signals in four of eight cases (Fig 3G-I; Table 2). As described already for Gals-1 and -3 in terms of occurrence, the tandem-repeat-type Gal-8 was present in most cases (14 from 15 cases), invariably localized in the cytoplasm, with added nuclear presence in three cases of the cribriform and solid types (Fig. 3J-L; Table 2).

In muco-epidermoid carcinomas (MEC; six cases) intermediate cells were always positive for Gal-1, mucus cell invariably negative (Fig. 4A). Overall, except for one case with Gal-8 positivity, staining was consistently cytoplasmic (Table 2). Intertumoral heterogeneity was observed for Gals-3 and -7 , with positivity restricted to intermediate cells in three cases (Fig. 4B, C). Immunolabelling for Gal-8 was observed cytoplasmically in both cell types in five from six cases (Fig. 4D; Table 2).

Acinic cell carcinomas (ACC; nine cases) were generally positive for Gal-1 in the intercalated duct-type cells (Fig. 5A). This nucleocytoplasmic staining pattern contrasted with 
Remmelink et al.

exclusively cytoplasmic positivity for Gal-3 in three of nine cases (Fig. 5B) and even complete lack of positivity for Gal-7 (Fig. 5C; Table 2). Gal-8, however, shared staining properties with Gal-1 in signal intensity and site of staining, four cases also presenting nuclear positivity (Fig. 5D; Table 2). This distribution is in conspicuous contrast to the profile of galectin presence in carcinoma ex pleomorphic adenomas (CA-ex-PA) with immunopositivity for Gals-1, -3 and -8 in all cases (Fig. 6A,B,D) and for Gal-7 in five of nine cases (Fig. 6C). Staining was invariably nucleocytoplsamic for Gal-1 and -7, in eight of nine cases exclusively cytoplasmic for Gal-8 (Table 2). Combining signal presence and localization adds up to a distinct signature. Among the 39 cases with malignancy, p53 was detectable in four cases (two ACCs, two CA-ex-PAs), of which one CA-ex-PA was strongly immunopositive for Gal7. Weak p16 ${ }^{\mathrm{INK} 4 \mathrm{a}}$-dependent signals were picked up in six cases (four AdCCs, two CA-exPA), always associated with Gal-1 presence.

Analyzing the quantitative data for each galectin with respect to the different tumour types (Fig. 7), an increase for Gal-1 pertains to the percentage of positive cells (LI parameter; Kruskall-Wallis: $p=0.001$ ). A highly significant difference (post-hoc comparison; $p=0.0006$ ) concerned the labelling index between the chondroid component in PAs and the CA-ex-PAs (Fig. 7B). These two correlations also showed up in the case of Gal-3, albeit with reduced level of statistical significance at $\mathrm{p}=0.01$ and $\mathrm{p}=0.004$, respectively (Fig. 7D). In contrast, presence of Gals-7 and -8 was subject to downregulation. Prominent differences in this respect led to a separation in two groups constituted by PA and the corresponding carcinoma vs the other three studied types of malignancy for Gal-7 in both categories of quantitative data (MOD, LI; Kruskall-Wallis: $\mathrm{p}<10^{-6}$ ) (Fig. 8A, B). Post-hoc comparisons between the CA-exPAs and AdCCs yielded p-values at 0.03 for the MOD parameter and at 0.01 for the LI variable. As shown in Fig. 8A, B, the epithelial component in PA showed strikingly stronger signal presence than cases with malignancy (also p-value for comparison to MECs at 0.01 for 
Remmelink et al.

MOD variable). The chondroid component, too, differed from adenoid cystic and acinic cell carcinomas. Concerning Gal-8, malignancies - except for the MECs - were associated with a decrease in signal (Fig. 8C, D). As documented in Fig. 8C, the groups of CA-ex-PAs and pleomorphic adenoma (epithelial component) were separated at $\mathrm{p}=0.03$ in post-hoc comparison. The difference between epithelial component of adenoma and AdCC reached significance for both quantitative parameters $(\mathrm{p}=0.049$ for the labelling index, here also for ACCs (Fig. 8C, D)). The p-value between the chondroid component and ACCs was at 0.02. Thus, while percentage of labelled cells for Gals-1 and -3 increased in CA-ex-PA, a decrease was noted for Gal-7 (excluding the CA-ex-PAs) and for Gal-8 (excluding MECs).

\section{Discussion}

Galectins are capable to turn presence of distinct glycans into cellular responses, e.g. in growth control of tumour cells $(16,19,22-25)$. In addition, they are also known to be present within the cell, and act in concert with distinct target proteins such as oncogenic $\mathrm{H}-$ ras or effectors in the apoptotic or splicing cascades (2, 26-28). As case studies for salivary gland tumours have documented (7-11), the investigation of this lectin group has so far mainly been focused on Gals-1 and -3 . Analysis of further family members, at best by fingerprinting studies, is at a rather early stage. Emerging data from head and neck tumours underscore its pertinence, i.e. by revealing association of presence of Gals-1 and -7 with progression to malignancy and inverse shifts between nuclear and cytoplasmic localization in laryngeal/hypopharyngeal squamous cell carcinomas as well as the upregulation of Gal-8 in these tumours in contrast to an often encountered downregulation in other tumour types, hereby strongly indicating intriguing divergence between different galectins $(17,29,30)$. In order to pursue these indications, a promising methodological approach exemplified in this study is a.) monitoring presence of galectins from the three subgroups in parallel 
Remmelink et al.

immunohistochemically, b.) determining their localization profiles and c.) assessing staining parameters quantitatively.

This study examines proto-type (Gal-1/-7), chimera-type (Gal-3) and tandem-repeat-type (Gal-8) galectins comparatively. It teaches several key lessons, starting with detection of a definitely non-uniform regulation of the individual, closely related proteins. The patterns of presence in PA with grading from Gal-8 to Gal-1, Gal-3 and finally Gal-7 illustrates this point. Of note, specimens of Warthin's tumour were consistently negative for Gal-1, while maintaining features for Gals-3, -7, and -8 (31). As internal standard for validity of inter-study comparison our data are in accord with high degree of positivity of Gal-3 in AdCCs (7-11). The stratification based on intracellular distribution disclosed notable shifts and differences. For pathologists, this point could be relevant in the histopathological MEC diagnosis because these tumours presented a unique profile based on cytoplasmic localization of Gals-1, $-\mathbf{3},-\mathbf{- 7}$, and $\mathbf{- 8}$ in the intermediate cells. Here, combination with Gal-7 presence has potential to increase the reliability of subtype diagnosis to separate solid-pattern from tubular/cribriform-patterns malignancies. Moreover, the absence of Gal-7 expression is also observed in ACC. This could help with distinction from MEC, especially the microcystic variant of ACC. When material is limited, the differential diagnosis between ADCCs and PAs is sometimes challenging. Our study shows that the expression profile of Gals-1, -3 , and -7 is different when considering these histopathological specimens. In PA, the absence of nuclear Gal-1 signal and the cytoplasmic and nuclear presence of Gal-3 constitute a characteristic Gal-1, -3 signature, whereas the Gal-3 signal was confined to the cytoplasmic compartment of ADCCs. Between CA-ex-PA and MEC/ACC/AdCC the signature of nucleocytoplasmic Gals-1/-3/-7 and cytoplasmic Gal-8 is rather specific, underscoring the potential of fingerprinting combined with staining-site monitoring. When positive (in six from 39 tumour cases), presence of the tumour suppressor p16 ${ }^{\mathrm{INK} 4 \mathrm{a}}$ was 
Remmelink et al.

associated with Gal-1 presence, in line with a role of this protein to enhance Gal-1 gene transcription (19). In summary, our study supports the concept for characteristic signatures of galectin presence when monitoring several proteins of this class, constituting progress in mapping presence of these lectins and indicating potential for differential diagnosis, especially for MEC/ACC.

\section{References:}

1. Cooper DNW. Galectinomics: finding themes in complexity. Biochim Biophys Acta 2002;1572;209-231.

2. Schwartz-Albiez R. Inflammation and glycosciences. In: The Sugar Code. Fundamentals of glycosciences (Ed. Gabius H-J), pp. 447-467. Wiley-VCH, Weinheim, Germany, 2009.

3. Gabius H-J, Brehler R, Schauer A, Cramer F. Localization of endogenous lectins in normal human breast, benign breast lesions and mammary carcinomas. Virch Arch [Cell Pathol] 1986;52;107-115.

4. Lahm H, André S, Hoeflich A et al. Comprehensive galectin fingerprinting in a panel of 61 human tumor cell lines by RT-PCR and its implications for diagnostic and therapeutic procedures. J Cancer Res Clin Oncol 2001;127;375-386.

5. Saussez S, Cucu DR, Decaestecker C et al. Galectin-7 (p53-induced gene-1): a new prognostic predictor of recurrence and survival in stage IV hypopharyngeal cancer. Ann Surg Oncol 2006;13;999-1009.

6. Cada Z, Smetana K Jr, Lacina L et al. Immunohistochemical fingerprinting of the network of seven adhesion/growth-regulatory lectins in human skin and detection of distinct tumor-associated alterations. Folia Biol 2009;55;145-152.

7. Xu XC, Sola Gallego JJ, Lotan R, El-Naggar AK. Differential expression of galectin-1 and galectin-3 in benign and malignant salivary gland neoplasms. Int $J$ Oncol 2000;17;271-276.

8. Penner CR, Folpe AL, Budnick SD. C-kit expression distinguishes salivary gland adenoid cystic carcinoma from polymorphous low-grade adenocarcinoma. Mod Pathol 2002;15;687-691.

9. Teymoortash A, Pientka A, Schrader C, Tiemann M, Werner JA. Expression of galectin-3 in adenoid cystic carcinoma of the head and neck and its relationship with distant metastasis. J Cancer Res Clin Oncol 2006;132;51-56. 
10. Ferrazzo KL, Alves SM Jr, Santos E, Martins MT, de Sousa SM. Galectin-3 immunoprofile in adenoid cystic carcinoma and polymorphous low-grade adenocarcinoma of salivary glands. Oral Oncol 2007;43;580-585.

11. Ferrazzo KL, Neto MM, dos Santos E, dos Santos Pinto D, de Sousa SO. Differential expression of galectin-3, $\beta$-catenin, and cyclin D1 in adenoid cystic carcinoma and polymorphous low-grade adenocarcinoma of salivary glands. J Oral Pathol Med:in press.

12. Nagy N, Legendre H, Engels $\mathrm{O}$ et al. Refined prognostic evaluation in colon cancer using immunohistochemical galectin fingerprinting. Cancer 2003;97;1849-1858.

13. Langbein S, Brade J, Badawi JK et al. Gene-expression signature of adhesion/growthregulatory tissue lectins (galectins) in transitional cell cancer and its prognostic relevance. Histopathology 2007;51;681-690.

14. Polyak K, Xia Y, Zweier JL, Kinzler KW, Vogelstein B. A model for p53-induced apoptosis. Nature 1997;389;300-305.

15. Bernerd F, Sarasin A, Magnaldo T. Galectin-7 overexpression is associated with the apoptotic process in UVB-induced sunburn keratinocytes. Proc Natl Acad Sci USA 1999;96;11329-11334.

16. Kopitz J, André S, von Reitzenstein C et al. Homodimeric galectin-7 (p53-induced gene 1) is a negative growth regulator for human neuroblastoma cells. Oncogene 2003;22;6277-6288.

17. Saussez S, Decaestecker C, Lorfevre F et al. Increased expression and altered intracellular distribution of adhesion/growth-regulatory lectins galectins-1 and -7 during tumour progression in hypopharyngeal and laryngeal squamous cell carcinomas. Histopathology 2008;52;483-493.

18. Cada Z, Chovanec M, Smetana K et al. Galectin-7: will the lectin's activity establish clinical correlations in head and neck squamous cell and basal cell carcinomas? Histol Histopathol 2009;24;41-48.

19. André S, Sanchez-Ruderisch H, Nakagawa H et al. Tumor suppressor $\mathrm{p} 16^{\mathrm{INK} 4 \mathrm{a}}$ : modulator of glycomic profile and galectin-1 expression to increase susceptibility to carbohydratedependent induction of anoikis in pancreatic carcinoma cells. FEBS J 2007;274;32333256.

20. Lohr M, Kaltner H, Lensch M, André S, Sinowatz F, Gabius HJ. Cell-type-specific expression of murine multifunctional galectin-3 and its association with follicular atresia/luteolysis in contrast to pro-apoptotic galectins-1 and -7. Histochem Cell Biol $2008 ; 130 ; 567-581$. 
Remmelink et al.

21. Saussez S, Decaestecker C, Mahillon V et al. Galectin-3 upregulation during tumor progression in head and neck cancer. Laryngoscope 2008;118;1583-1590.

22. Kopitz J, von Reitzenstein C, André S, et al. Negative regulation of neuroblastoma cell growth by carbohydrate-dependent surface binding of galectin-1 and functional divergence from galectin-3. J Biol Chem. 2001;276:35917-35923.

23. Fischer C, Sanchez-Ruderisch H, Welzel M, et al. Galectin-1 interacts with the $\alpha_{5} \beta_{1}$ fibronectin receptor to restrict carcinoma cell growth via induction of p21 and p27. J Biol Chem. 2005;280:37266-37277.

24. Patsos G, André S, Roeckel N et al. Compensation of loss of protein function in microsatellite-unstable colon cancer cells (HCT116): a gene-dependent effect on the cell surface glycan profile. Glycobiology 2009;19;726-734.

25. Gabius H-J, ed. The Sugar Code. Fundamentals of glycosciences. Weinheim, Germany: Wiley-VCH; 2009.

26. Rotblat B, Niv H, André S, Kaltner H, Gabius HJ, Kloog Y. Galectin-1(L11A) predicted from a computed galectin-1 farnesyl-binding pocket selectively inhibits Ras-GTP. Cancer Res 2004;64;3112-3118.

27. Wang JL, Gray RM, Haudek KC, Patterson RJ. Nucleocytoplasmic lectins. Biochim Biophys Acta 2004;1673;75-93.

28. Smetana K Jr, Dvoránková B, Chovanec M et al. Nuclear presence of adhesion/growthregulatory galectins in normal/malignant cells of squamous epithelial origin. Histochem Cell Biol 2006;125;171-182.

29. Danguy A, Rorive S, Decaestecker C et al. Immunohistochemical profile of galectin-8 expression in benign and malignant tumors of epithelial, mesenchymatous and adipous origins, and of the nervous system. Histol Histopathol 2001;16;861-868.

30. Cludts S, Decaestecker C, MahillonV et al. Galectin-8 upregulation during hypopharyngeal and laryngeal tumor progression and comparison with galectins-1, -3 , and -7. Anticancer Res 2009,29:4933-4940.

31. Saussez S, de Leval L, Decaestecker C et al. Galectin fingerprinting in Warthin's tumors: lectin-based approach to trace its origin? Histol Histopathol 2010,25:541-550. 
Remmelink et al.

\section{Legends to Figures}

Figure 1: Immunohistochemical staining profiles for galectins-1, $-3,-7$ and -8 in intralobular (A, C, E, G), and in interlobular ducts (B, D, F, H). Magnification A-H x 320.

Figure 2: Immunohistochemical staining profiles for galectins-1, $-3,-7$, and -8 in epithelial (A-D) and in chondroid compartments (E-H) of PA. Magnification A-H x 320.

Figure 3: Immunohistochemical staining profiles for galectins-1, $-3,-7$, and -8 in solid (A, D, G, J), cribriform (B, E, H, K), and in tubular (C, F, I, L) AdCCs. Magnification A-H x 320.

Figure 4: Immunohistochemical staining profiles for galectins-1, $-3,-7$, and -8 in MEC (A-D). Magnification A-H x 320.

Figure 5: Immunohistochemical staining profiles for galectins-1, -3, -7, and -8 in ACC (A-D). Magnification A-H x 320.

Figure 6: Immunohistochemical staining profiles for galectins-1, $-3,-7$, and -8 in CA-ex-PA (A-D). Magnification A-H x 320.

Figure 7: Quantitative determination (by computer-assisted microscopy) of the percentages of cells immunopositive for galectins-1 or -3 (the Labelling Index, LI) $(\mathrm{B}, \mathrm{D})$ and the respective staining intensity (the Mean Optical Density, MOD) (A, C) in a series of 34 PA (20 cases of e-PA and 15 cases of c-PA), nine Ca-ex-PA, six MEC, 15 AdCC and nine ACC. Post-hoc comparisons were used to compare pairs of groups indicated by the arrow.

Figure 8: Quantitative determination (by computer-assisted microscopy) of the percentages of cells immunopositive for galectins-7 or -8 (the Labelling Index, LI) $(\mathrm{B}, \mathrm{D})$ and the respective staining intensity (the Mean Optical Density, MOD) (A, C) in a series of 34 PA (20 cases of e-PA and 15 cases of c-PA), 9 Ca-ex-PA, 6 MEC, 15 AdCC and 9 ACC. Post-hoc comparisons were used to compare pairs of groups indicated by the arrow. 
Remmelink et al.

Table 1: Clinical data

\begin{tabular}{|l|}
\hline Benign Salivary Gland Tumors \\
\hline -Sex : 38 females/34males \\
-Age: 46.3 years (range between 14 and 77 years) \\
-Localization: 72 parotid tumors \\
-Treatment: 72 superficial parotidectomies. \\
-Histology: 72 cases of pleomorphic adenoma \\
\hline Malignant Salivary Gland Tumors \\
-Sex: 22 females/ 17 males \\
-Age: 52.4 years (range between 19 and 88 years) \\
-Localization: 3 sub-mandibular specimens \\
7 oral cavity specimens \\
29 parotid specimens \\
-Histology: 15 cases of adenoid cystic carcinoma \\
9 cases of mucoepidermoid carcinoma \\
6 cases of acinic cell carcinoma.
\end{tabular}


Remmelink et al.

Table 2: Intracellular localization of galectins $-1,-3,-7$ and $-8^{\text {a }}$

\begin{tabular}{|c|c|c|c|c|c|c|c|c|c|c|c|c|}
\hline Type of tissue & \multicolumn{3}{|c|}{ Galectin-1 } & \multicolumn{3}{|c|}{ Galectin-3 } & \multicolumn{3}{|c|}{ Galectin-7 } & \multicolumn{3}{|c|}{ Galectin-8 } \\
\hline & \multicolumn{3}{|c|}{ Localization } & \multicolumn{3}{|c|}{ Localization } & \multicolumn{3}{|c|}{ Localization } & \multicolumn{3}{|c|}{ Localization } \\
\hline & $\mathrm{C}$ & $\mathrm{N}$ & $\mathrm{C}+\mathrm{N}$ & $\mathrm{C}$ & $\mathrm{N}$ & $\mathrm{C}+\mathrm{N}$ & $\mathrm{C}$ & $\mathrm{N}$ & $\mathrm{C}+\mathrm{N}$ & $\mathrm{C}$ & $\mathrm{N}$ & $\mathrm{C}+\mathrm{N}$ \\
\hline $\begin{array}{l}\text { Intralobular } \\
\text { ducts } \\
\text { Interlobular } \\
\text { ducts }\end{array}$ & $\begin{array}{l}0 \\
0\end{array}$ & $\begin{array}{l}0 \\
0\end{array}$ & $\begin{array}{l}25(100 \%) \\
22(100 \%)\end{array}$ & $\begin{array}{l}0 \\
0\end{array}$ & $\begin{array}{l}0 \\
0\end{array}$ & $\begin{array}{l}25(100 \%) \\
25(100 \%)\end{array}$ & $\begin{array}{l}0 \\
0\end{array}$ & $\begin{array}{l}0 \\
0\end{array}$ & $\begin{array}{l}14(100 \%) \\
14(100 \%)\end{array}$ & $\begin{array}{l}28(100 \%) \\
28(100 \%)\end{array}$ & $\begin{array}{l}0 \\
0\end{array}$ & $\begin{array}{l}0(0 \%) \\
0(0 \%)\end{array}$ \\
\hline $\begin{array}{l}\text { Pleomorphic } \\
\text { adenoma: } \\
\text { epithelial } \\
\text { component } \\
\text { chondroid } \\
\text { component }\end{array}$ & $\begin{array}{l}0 \\
0\end{array}$ & 0 & $\begin{array}{l}52(100 \%) \\
33(100 \%)\end{array}$ & $\begin{array}{l}29(59 \%) \\
10(43 \%)\end{array}$ & 0 & $\begin{array}{l}20(41 \%) \\
13(57 \%)\end{array}$ & $\begin{array}{l}2(5 \%) \\
0\end{array}$ & $\begin{array}{l}3(7 \%) \\
2(13 \%)\end{array}$ & $\begin{array}{l}38(88 \%) \\
14(87 \%)\end{array}$ & $\begin{array}{l}1(2 \%) \\
0\end{array}$ & 0 & $\begin{array}{l}64(98 \%) \\
36(100 \%)\end{array}$ \\
\hline $\begin{array}{l}\text { Adenoid cystic } \\
\text { carcinoma: } \\
\text { Tubular type } \\
\text { cribriform type } \\
\text { solid type }\end{array}$ & $\begin{array}{l}0 \\
0 \\
0\end{array}$ & $\begin{array}{l}2(100 \%) \\
3(60 \%) \\
0\end{array}$ & $\begin{array}{l}0(0 \%) \\
2(40 \%) \\
8(100 \%)\end{array}$ & $\begin{array}{l}2(100 \%) \\
5(100 \%) \\
6(100 \%)\end{array}$ & $\begin{array}{l}0 \\
0 \\
0\end{array}$ & $\begin{array}{l}0(0 \%) \\
0(0 \%) \\
0(0 \%)\end{array}$ & $\begin{array}{l}0 \\
0 \\
0\end{array}$ & $\begin{array}{l}0 \\
0 \\
0\end{array}$ & $\begin{array}{l}0 \\
1(100 \%) \\
4(100 \%)\end{array}$ & $\begin{array}{l}1(100 \%) \\
2(40 \%) \\
5(63 \%)\end{array}$ & $\begin{array}{l}0 \\
0 \\
0\end{array}$ & $\begin{array}{l}0 \\
3(60 \%) \\
3(37 \%)\end{array}$ \\
\hline $\begin{array}{l}\text { Mucoepidermoid } \\
\text { carcinoma }\end{array}$ & $6(100 \%)$ & 0 & 0 & $3(100 \%)$ & 0 & $0(0 \%)$ & $\begin{array}{l}3 \\
(100 \%)\end{array}$ & 0 & 0 & $5(83 \%)$ & 0 & $1(17 \%)$ \\
\hline $\begin{array}{l}\text { Acinic cell } \\
\text { carcinoma }\end{array}$ & 0 & 0 & $9(100 \%)$ & $3(100 \%)$ & 0 & $0(0 \%)$ & 0 & 0 & 0 & $5(56 \%)$ & 0 & $4(44 \%)$ \\
\hline $\begin{array}{l}\text { Carcinoma ex } \\
\text { pleomorphic } \\
\text { adenoma }\end{array}$ & 0 & 0 & $9(100 \%)$ & $4(44 \%)$ & 0 & $5(56 \%)$ & 0 & 0 & $5(100 \%)$ & $8(89 \%)$ & 0 & $1(11 \%)$ \\
\hline
\end{tabular}

${ }^{a}$ separated into presence of signal in cytoplasm (C) and/or nuclei (N). For each type of tissue, the number of cases and the percentage of immunopositive cases relative to the intracellular localization are provided. 

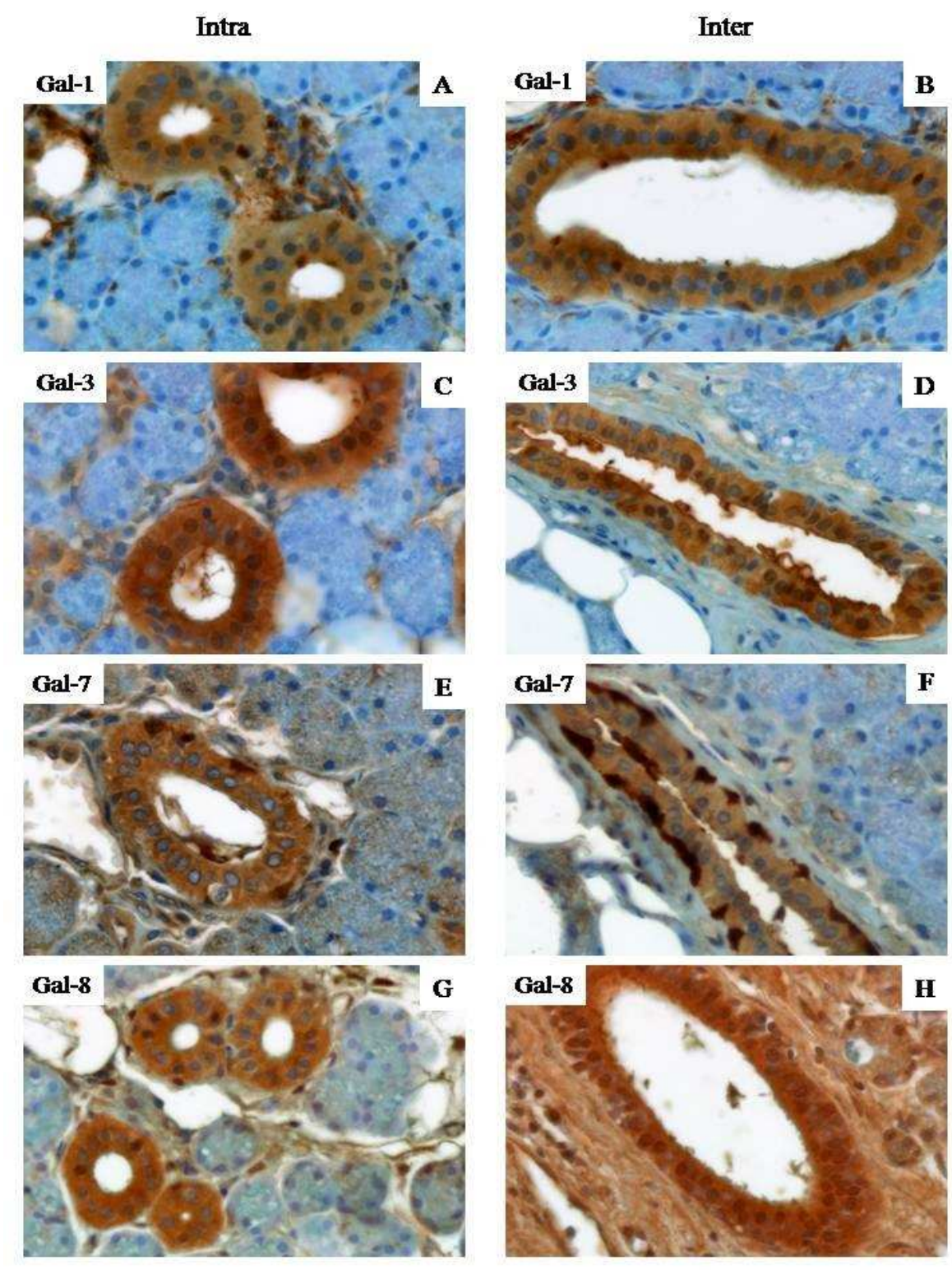

figure 1

$190 \times 254 \mathrm{~mm}(96 \times 96 \mathrm{DPI})$ 

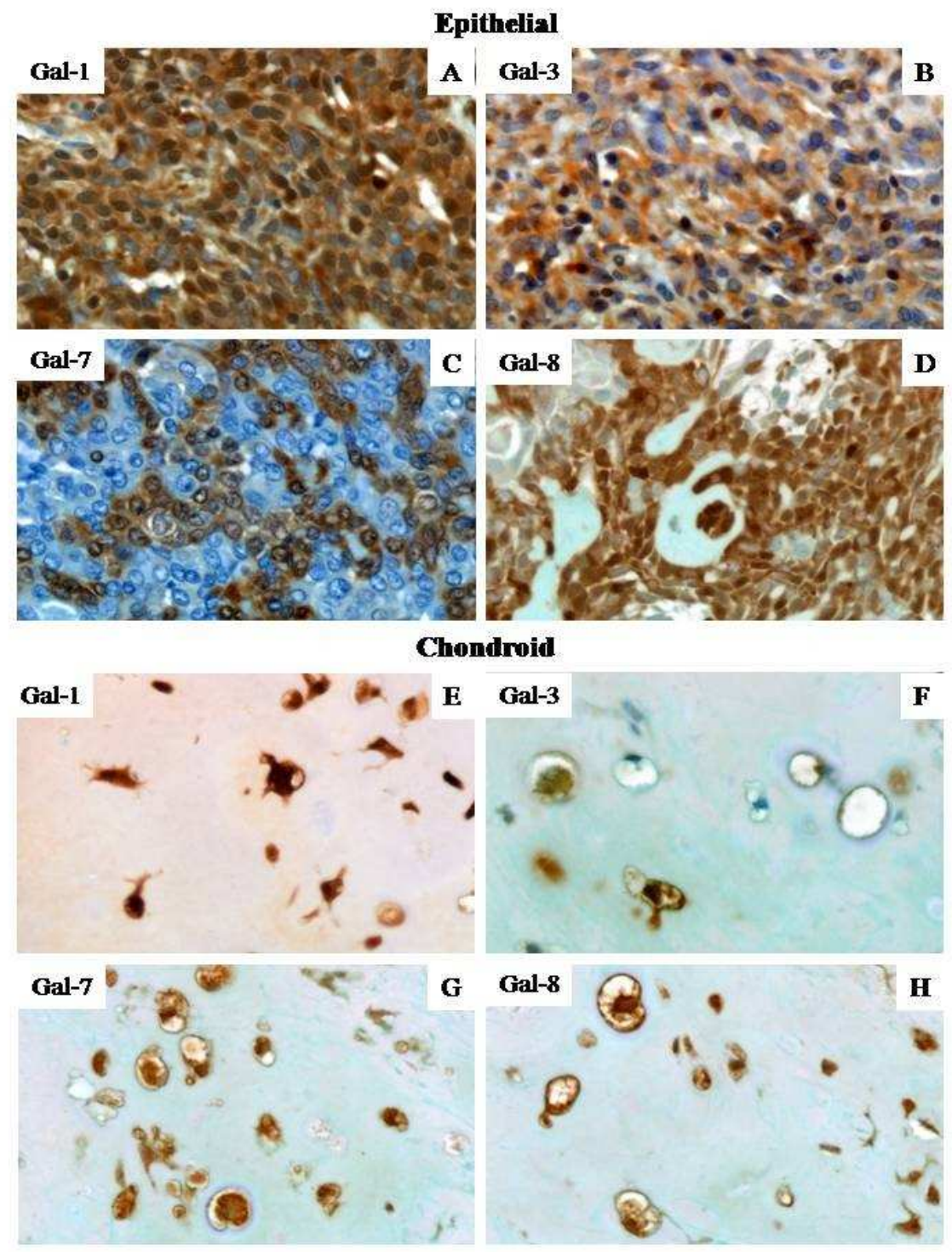

figure 2

$190 \times 254 \mathrm{~mm}(96 \times 96 \mathrm{DPI})$ 
Solid
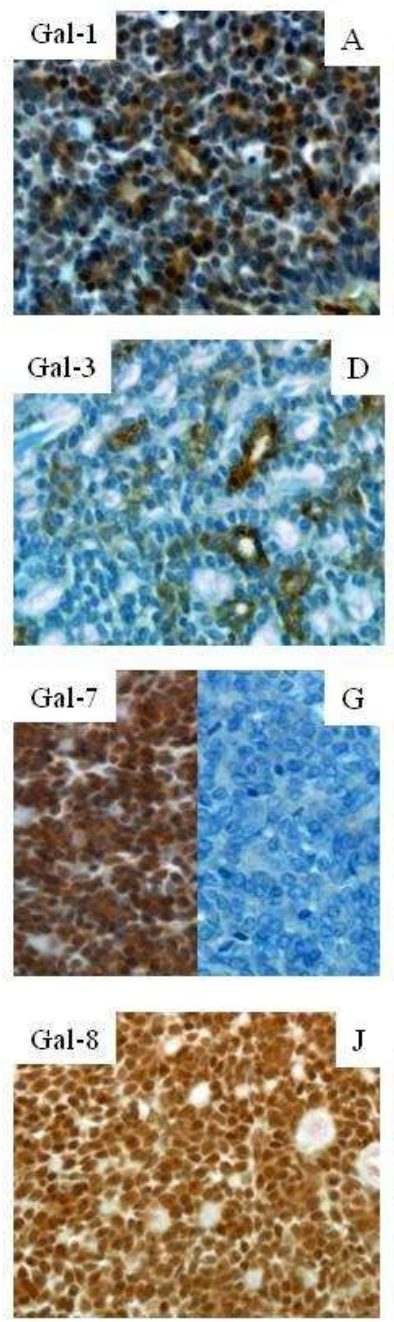

Cribriform
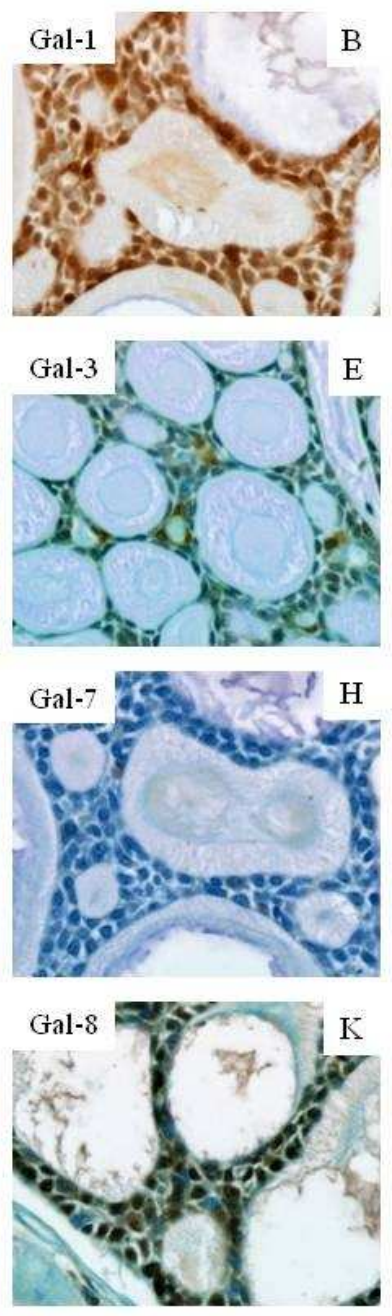

Tubular
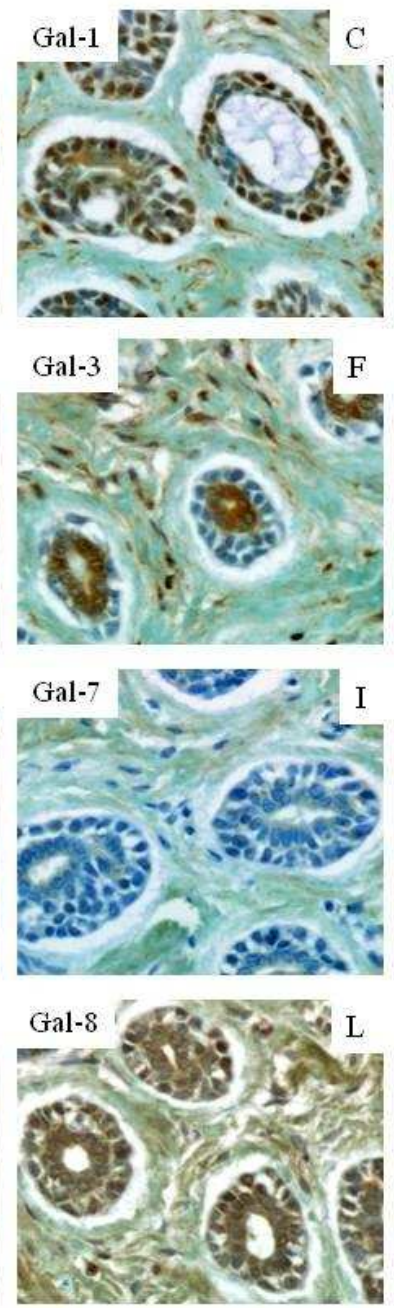

figure 3

$190 \times 254 \mathrm{~mm}(96 \times 96 \mathrm{DPI})$ 

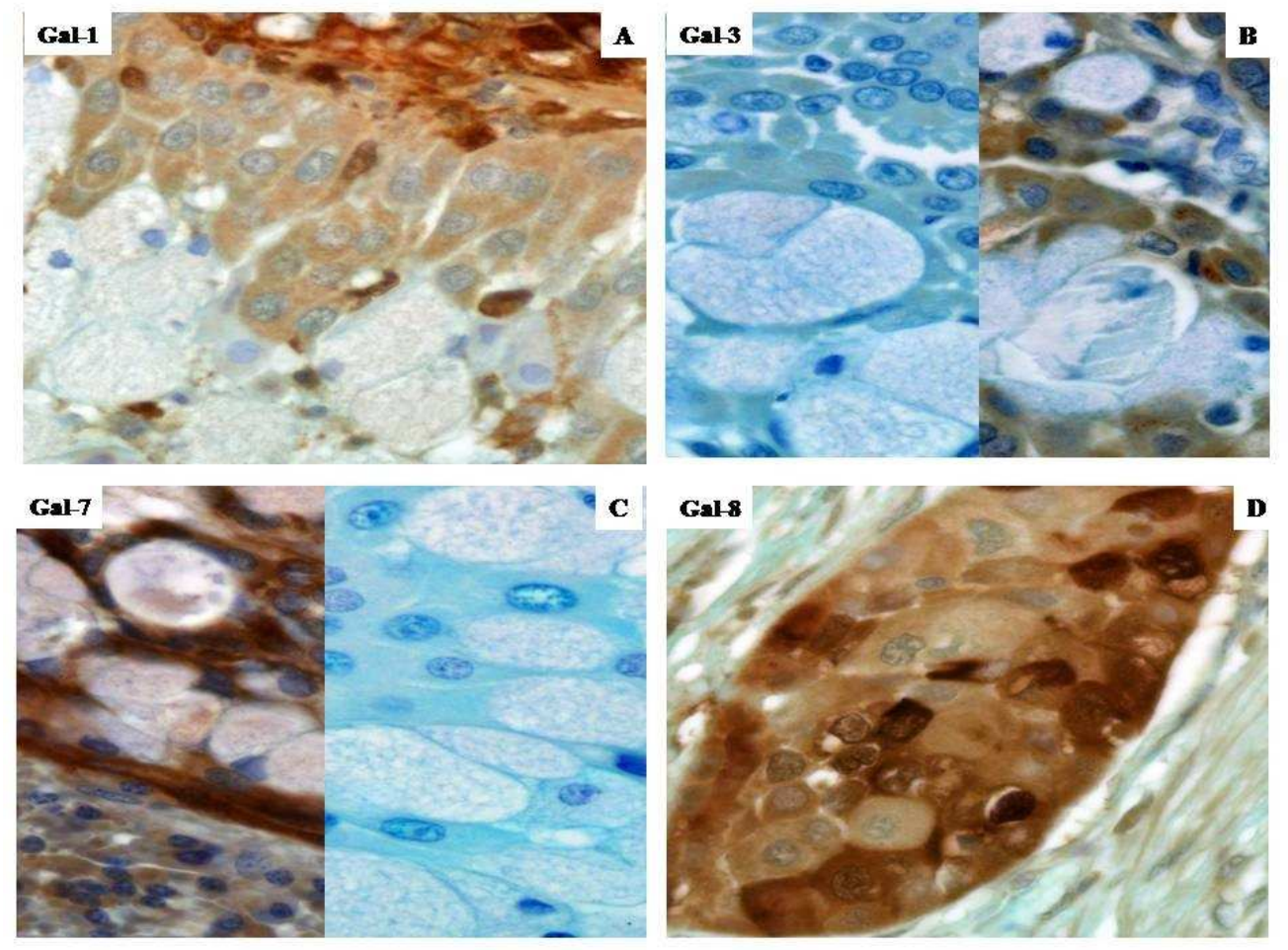

figure 4

$254 \times 190 \mathrm{~mm}(96 \times 96 \mathrm{DPI})$ 

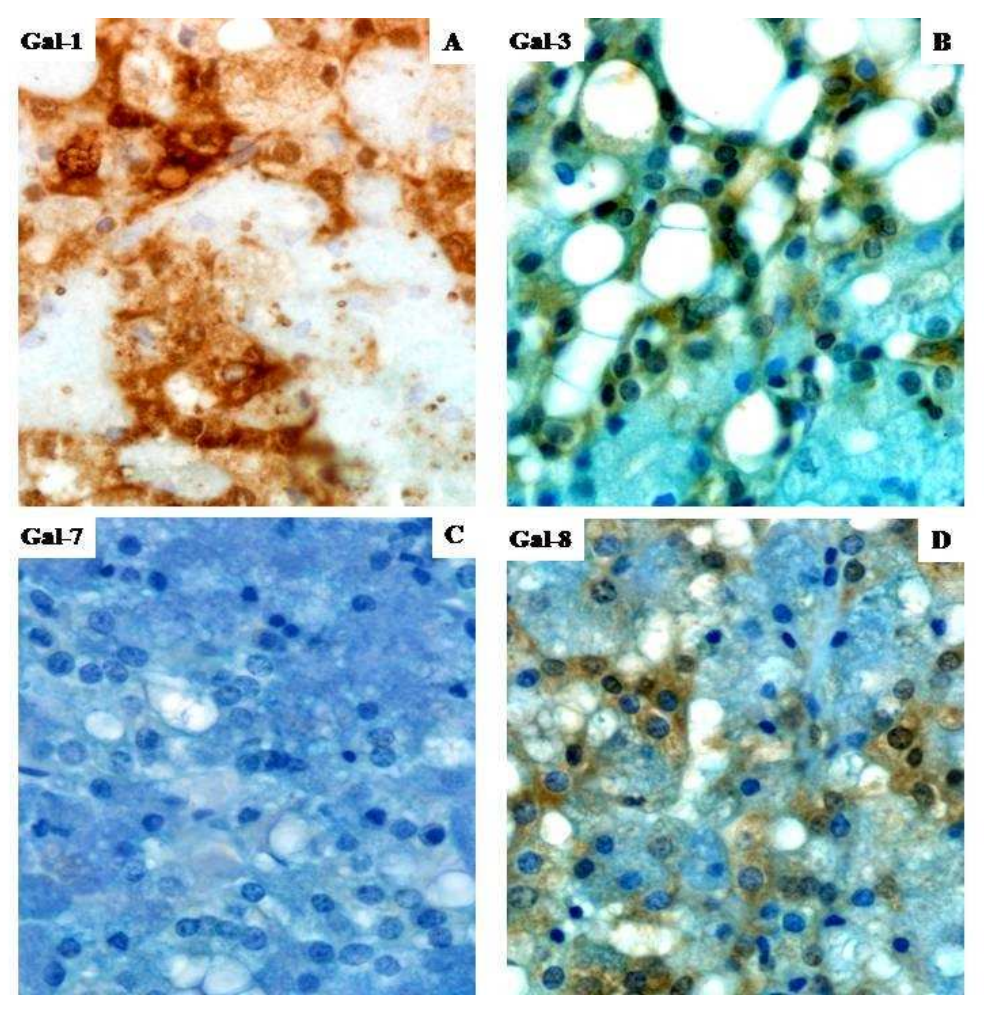

figure 5

$254 \times 190 \mathrm{~mm}(96 \times 96 \mathrm{DPI})$ 


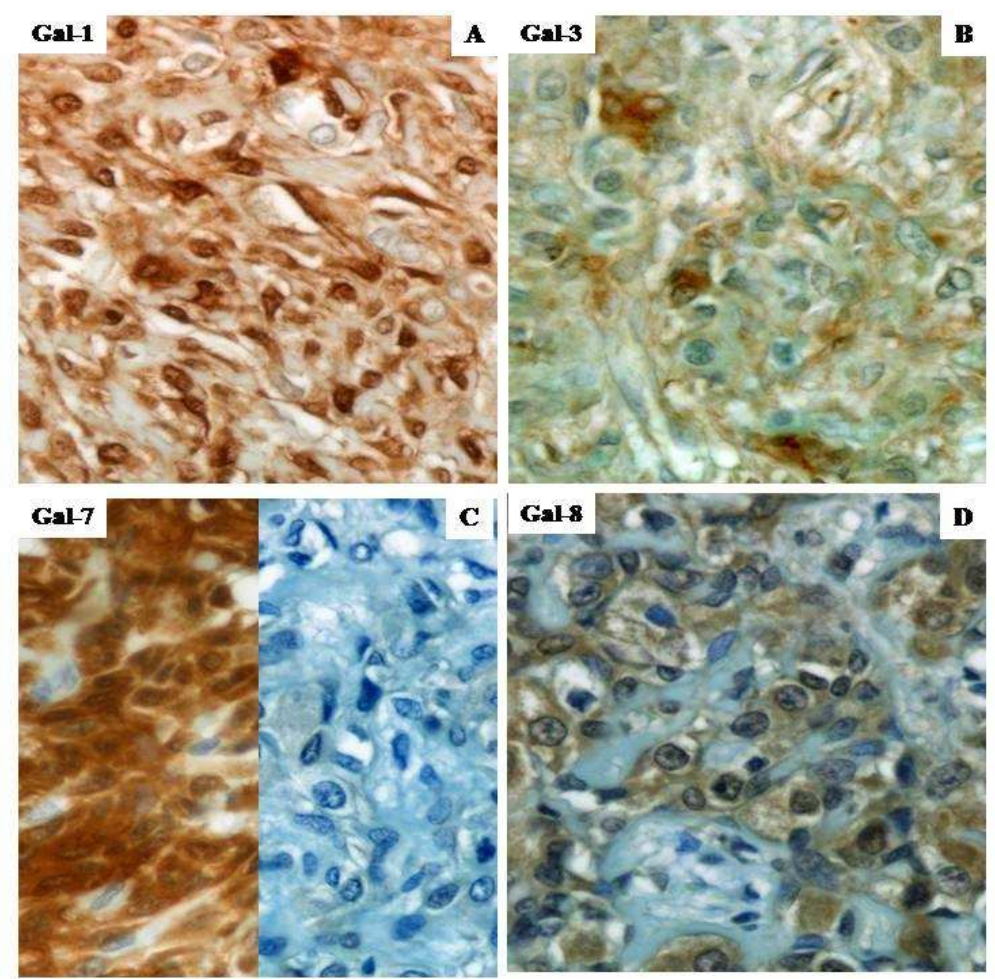

figure 6

$254 \times 190 \mathrm{~mm}(96 \times 96 \mathrm{DPI})$ 

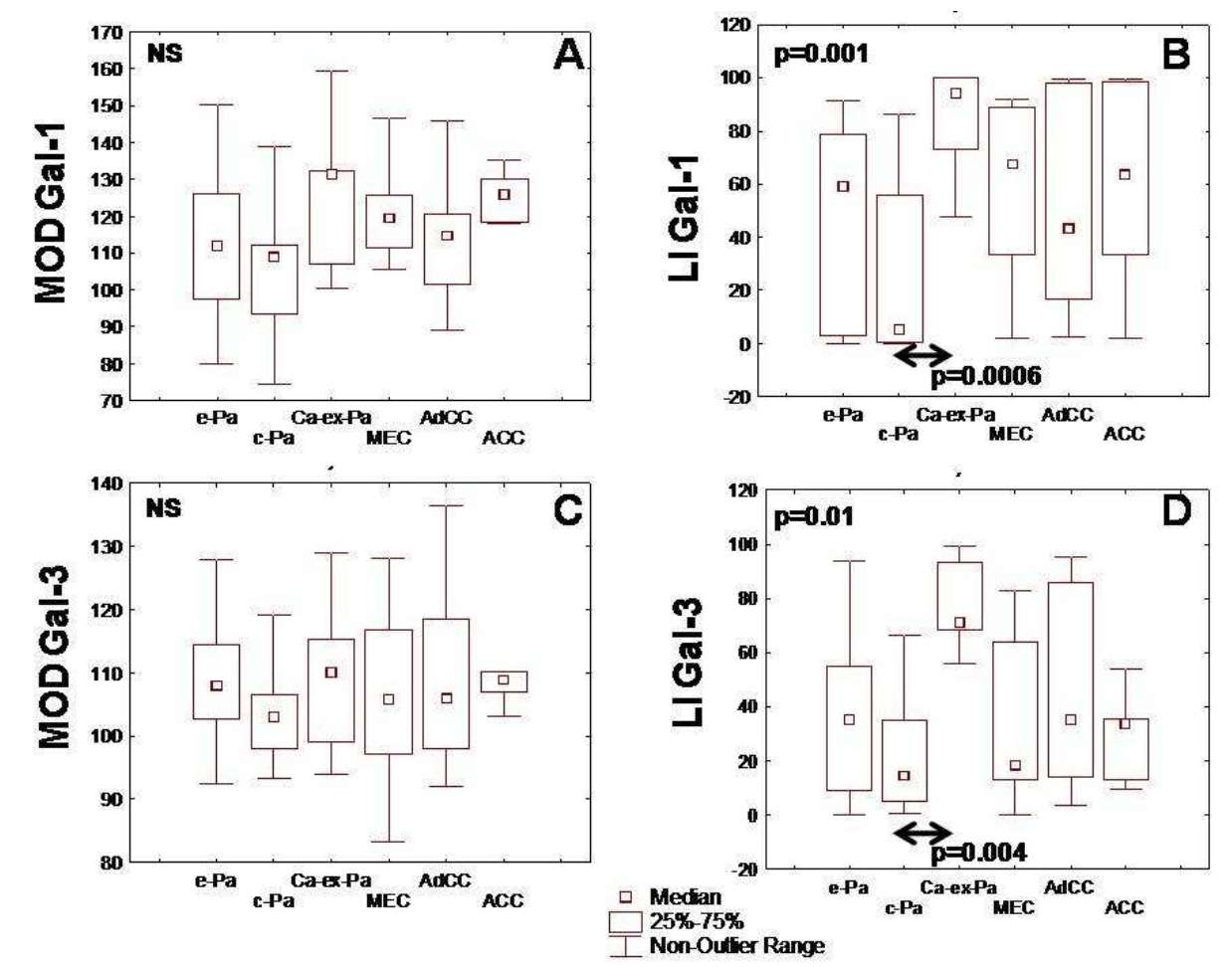

$254 \times 190 \mathrm{~mm}(96 \times 96$ DPI $)$ 

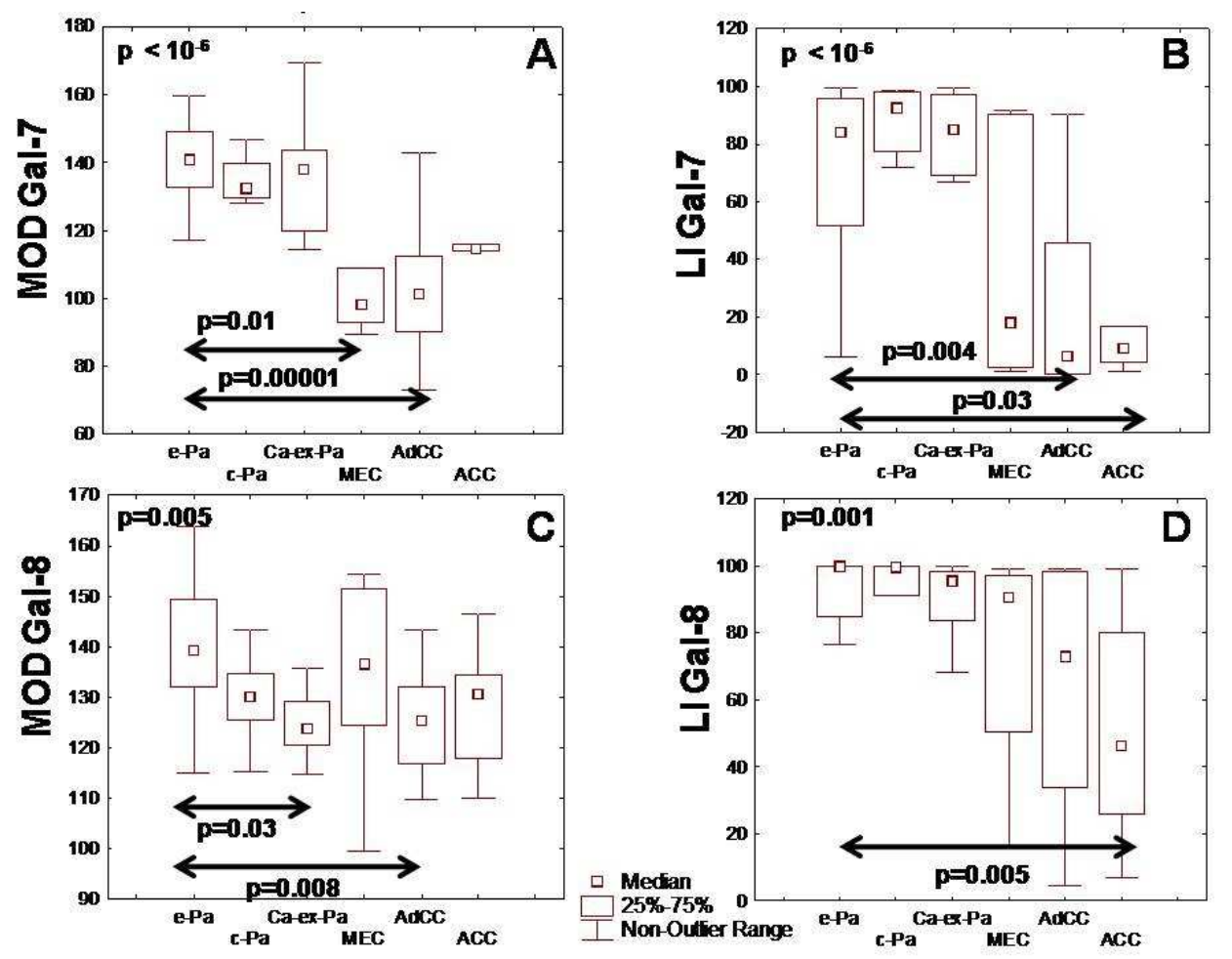

figure 8

254x190mm (96 x 96 DPI) 